\title{
Using Dry Ports to Facilitate International Trade in Iran; A Model of Success Factors for Implementation of Dry Ports
}

\author{
Sayyed Hassan Hatami-nasab ${ }^{1}$, Ali Sanayei ${ }^{2}$, S. F. Amiri Aghdaei $^{3}$ \& Ali Kazemi ${ }^{4}$ \\ ${ }^{1}$ Ph.D Student of Marketing Management, Dept. of Management, University of Isfahan, Isfahan, Iran \\ ${ }^{2}$ Professor of Marketing Management, Head of Management Research Institute, University of Isfahan, Isfahan, \\ Iran \\ ${ }^{3}$ Assistant Professor of Marketing Management, Faculty of Economic \& Official Sciences, University of Isfahan, \\ Isfahan, Iran \\ ${ }^{4}$ Assistant Professor of Marketing Management, Faculty of Economic \& Official Sciences, University of Isfahan, \\ Isfahan, Iran \\ Correspondence: Sayyed Hassan Hatami-nasab, Dept. of Management, University of Isfahan, Isfahan, Iran. \\ E-mail: hatami2157@gmail.com
}

Received: December 10, 2015

Accepted: January 10, 2016

Online Published: February 29, 2016

doi:10.5539/mas.v10n3p155

URL: http://dx.doi.org/10.5539/mas.v10n3p155

\begin{abstract}
As coastal production costs in many countries, producers are moving inland to remain competitive with other countries. Also, container transport volumes continue to grow, the sea flow generates almost proportional inland flow; the links with hinterland will become critical factors for the seaports functionality. Development of dry ports is an important part of intermodal transport which play an important role in improving hinterlands. Successful implementation dry port depends on identification and description of required capabilities to develop advanced intermediate terminal, discover existing deficiency in these capabilities and their effects of each other. This article fill the gaps of implementation of dry ports by offering a conceptual model. To do so, this current study is done in a complicated process in five stages of: review of literature, Delphi, Gap analysis, fuzzy Dematel and Structural equation modeling (SEM). 17 indexes of Delphi model were extracted and classified in 8 groups. The identified gap and causal relations enabled presentation of a model which was tested and verified by Partial Least Squares (PLS).
\end{abstract}

Keywords: international trade, hinterland, intermodal transport, dry port, Iran

\section{Introduction}

Existing problems in transportation network traffic in the world has led to many countries make use of intermodal transport, such as dry ports, which has a significant role in improvement and development of status of goods transportation, especially Container products. The dry port concept is based on a seaport directly connected by rail with inland intermodal terminals where containers can be dealt with in the same way as if they were in a seaport. Intermodal transport with dry ports could be a potential solution for seaport terminal congestion as well as for better seaport inland access that might be based on short haul rail. Intermodal transport is generally considered to be viable on markets with larger flows or longer distances; however, due to cost of congestion, growing environmental constraints, but also due to competition between seaports, the break-even distance for inland intermodal transport could be very market dependent.

In United States, Brazil, Canada in America, Spain, Italy, Germany, Belgium, Denmark, Sweden, France, Finland and Netherland in Europe, Australia and New Land in Pacific, United Arabic Emirates, Pakistan, Philippine, Cambodia, India in Asia, and Tanzania, Swaziland and Ghana in Africa different type of dry ports are set up. However, regarding vast waterfront areas and high volume of import and export goods in Iran, there always been traffic problem in water ports. For instance, improvement of container performance of Shahid-Rajaei as the greatest container port in the country, which was more than 2 million TEU and its rank was 67. Recent growth of this port and its estimated trend (such as physical improvement of terminal container port) led to increase of internal container transportation operation. But, in contrast to the development, the containers stop more than standard time in this port (27 compared to 3 to 5 days of international standard). As this condition 
is seen more or less in other ports, traditional structure of internal container transportation which $90 \%$ is done by means of road transportation (that is done mainly dead mileage) along with use of a high amount of fuel, environmental pollution and increase of road traffic (that causes many potential events) introduced various problems (Note 1). One of the strategies which had successful experiences in many countries is dry port.

To improve intermodal transport, transportation links such as highways, rail networks and internal waterways should be improved. Clearly, considering the above factors and their implementations would lead to accelerate the developing dry ports and intermodal transport in the country. This current study seeks to find main factors and to present a related conceptual model.

\section{Theories and Literature Review}

Concept of dry port is somewhat new and it has different definitions. Rardrik et al. (2010) defined dry ports as inland ports. That is, there is no precise understanding about how to define dry port or inland ports.

Roso and Lumsden (2010) based on previous studies related to terminal facilities, used concepts of dry port. They defined it as "dry port is a central and inland terminal which is directly connected to sea ports and has high capacity of vehicles and users can deliver or receive standard units of goods. As if this operation is done ports." Notteboom and Rodrigue (2009) identified three hinterlands: macroeconomic hinterlands, facilitation areas and logistic areas. He explained that each area is under the effect of environmental structures and complicated functions. Moreover, other researchers such as Frémont and Soppé (2007), Notteboom (2004), Notteboom and Winklemans (2001) stated that many sea ports and shipping lines are integrated to control transportation of hinterlands. This vertical integration should be done carefully and opposite resolutions should honor great unions. As treaties and conferences of sharing free spaces on sea is accepted, but opposite authorities in court of European Commission are opposed to each other (Olivier and Slack, 2006). With advent of new port networks (Notteboom, 2004) and different factors which are vertically integrated vertically, competitive situation required continuous attention of port operators (Frémont and Soppé, 2007, Notteboom and Winklemans, 2001). Traditional hinterlands are based on numerous road connections and some railways.

\section{Effective Factors for Implementation of Dry Port}

As a result of revolution in international industry of transportation and freight based on changes and continuous development in managerial innovations, provisions and technology, global trade and globalization of districts and regions are increasingly prosperous. Especially for container ports, there is a need of dynamic nature of such an environment to significantly increase size of container ships (Cullinane and Khanna, 1999, 2000; Imai et al., 2006), to justify activities of moving cargos in order to achieve more efficiency (Cordeau et al, 2001; Kim and Moon, 2003; Park and Kim, 2003; Vis and Koster, 2003; Christiansen et al., 2004; Guan and Cheung, 2003; Hansen et al., 2008; Cullinane, 2010), to develop control of port (Brooks and Cullinane, 2007) and the need to redirect port services marketing in order to find standard position in logical and standard competitive supply chain compare to remote lands (Robinson, 2002).

Therefore, having a solution to solve potential problems and multidimensional conflicts is vital and important. These problems can be the need of improving capacity, environmental considerations, relational limitations (not the geographical limitations) and continuous establishment of transportation and logistics in integrated supply chain. One of the solutions that is often considered both in practice and as an identifiable research area is the concept of "dry port".

As it is clear from the concept, a dry port is defined as a ground terminal for shipping lines in which loading is done and this concept is applicable for all kinds of cargos (UNCTAD, 1982). However, not only this concept in theory and in practice is closely related to making transportation container-based and making related changes (UNCTAD, 1991), but also it should have common characteristic applicable for different structures. This common characteristic is a spot on earth which has all functions of a port (Cullinane and Wilmsmeier, 2011).

In addition to necessity of safe and scheduled railway connections in order to have internal access to sea ports, security in dry ports is also important, especially during custom clearance. Implementation of international ports and shipping includes making changes in physical design, which leads to security in port and its facilities. It also needs some changes current activities of port which makes implementation of dry ports expensive.

After studying disability of Egypt sea ports, Vandervoort and Morgan (1999) suggest that dry port should be fitted and appropriate by a complicated system in which supportive and necessary infrastructures, guaranteed repair and maintenance, and legal and organizational system are correctly designed; so that public and private centers get involved.

Van Klink and Van den Berg (1998) studied subside condition of rail transportation and economic collaboration. 
They concluded that lack of national subside and group help are great obstacle to develop intermodal transportation. On the other hand, Baird (2004) shows that government investment in sea ports needs a proper evaluation and judgment. Therefore, government has a significant role in implementation of terminals.

Another important factor is pollution source of transportation that is increased by globalization and trade. According to Roso (2008) a train can replace 34 to 40 trucks that can reduce negative environmental impact around the road connected to sea ports, such as air pollution, sound pollution. As Roso and Lumsden (2010) showed in their researches and investigations, intermodal transportation as an instrument to solve environmental problems is so far used. Implication of dry port might be justified based on profit motive, even if it is appropriate from some aspect of economic before taking more normal approaches in to consideration. While it may mean that dry port are more relevant to developing economic period or in prosperous periods than recession period, but developing the capacity is not the only reason of implication of dry port (Bergqvist and Wilmsmeier, 2011).Moreover, the findings showed that dry port concept can help to identify some other ways for transporting high volume of load that are more efficient and less harmful for the environment, they can reduce population in port cities and develop logistic solution for shipping companies in the country (Roso, Woxenius and Lumsden, 2009).

Dry port and load hubs Locating is an important factor that should be considered. Many investigations have been done during the analysis of intermodal systems and locating dry ports and hubs, which is considered as an important factor to be analyzed (Monios, 2010). Implementation of dry port concept in Sweden (in which transporting loads from sea port by trucks replaced by train), led to reduction of $25 \%$ emission of pollutant and traffic in the port (Roso, 2007). Research of Liao, Tseng and Lu (2009) in Northern Taiwan showed that transportation by means of intermodal transportation by ship, shore facilities and trucks is so effective and loading efficiency resulted in $60 \%$ reduction in pollution. Another research by Liao et al. (2010) illustrated more reduction in $\mathrm{Co} 2$ by changing the direction of established ports to new port of Taipei. Regarding pollution of transportation in London, Zanni and Bristow (2009) stated that integration and using intermodal distribution channels led to $25.7 \%$ reduction of pollution. Dry port can also reduce trip of empty trucks. For instance $12 \%$ to $30 \%$ of trucks move empty in Pakistan andin China, $43 \%$ of trucks have the same problem (Londono-Kent, 2009). Improvement in organizing facilities, coordination and planning of path also can decrease pollutant gas from $10 \%$ to $20 \%$ around the world (OECD, 2010).

As Buehler et al (2005) pointed out, one policy issue that needs to be addressed is coordination among the various government agencies involved in the development of dry ports, including those responsible for licensing, investment, promotion of private-sector initiatives, etc. Both government and the private sector need to work together to develop intermodal transport in Asia that not only provides access to inland and landlocked areas but also promotes environmentally friendly freight transport. In briefly speaking, many researcher tried to find main Factors of Promoting intermodal freight transport through the development of dry ports in theirs countries. However, despite desirable condition for all the factors mentioned (i.e. location of dry port, emission of $\mathrm{CO} 2$ on environment, roads, rails and sea situation, infrastructures, financial capital, etc.), can contribute to the success of dry ports. Obviously, these factors have direct and indirect effects on each other that awarding about these relationships provides the suitable situation for effective using of them. Therefore, this paper is identified and provided a conceptual model of the relationship between these factors.

\section{Methodology}

In in this current study integrated approach (combination of qualitative and quantitative) is used. First, qualitative data are collected and then defined relationships based on qualitative data are evaluated by quantitative methods.

Regarding significance of the research area, it is required that research subject be done based on the conditions and data related to Iran. In order to answer the first question (which items are important in setting up a dry port?), this study is started by qualitative approach to find capability and requirement of dry port implementation. In this stage, meanwhile review of literature is done by means exploratory interviews with expertise, related dimensions and factors re identified. Also, authors used Delphi technique for more accurate identification of items and achieve more comprehensive view.

In the second part of research process, requirements and capabilities of implementation of dry port are analyzed based on quantitative approach with qualitative theme. This part addressed the second question of research (Is there a gap between expected and presented perceived situation of identified factors?). The results are also used to design a Paired comparisons questionnaire for causal analysis of factors.

In the third part, library studies are reviewed again and based on obtained data from previous stages, a primary 
model for research is presented based on the third question (Which model shows the relationships between these factors?) and a tool to evaluate reliability and the importance of variants relationship in the statistical population will be designed and tested. As this part of study is done in a real environmental situation, it is considered a field study; and because data collection is based on questionnaire, it is considered a survey. The third part is also a causal research as causal relationship of factors is taken in to consideration.

In the part that qualitative approach is used (Delphi questionnaire and paired comparison), validity and reliability of tool is verified by evaluators' evaluative method. In qualitative approach (gap analysis questionnaire and test model), validity is verified by content validity method (expertise idea), construct validity (Convergent validity: AVE criterion and divergent validity: comparison of the correlation between indexes of one construct with the construct against correlation of those indexes with other constructs) and reliability is verified by composite reliability of constructs method, Cronbach's alpha and internal consistency.

\section{Statistical Population and Sample}

Research is done in Iran and statistical population is all experts and managers in chamber of commerce and executive department (governor generals). Regarding high number of members, statistical population is unlimited.

In first part of questionnaire data collection which is done by Delphi method, required data collected by snowball method. Primary group of experts were interviewed and then they were asked to introduce proper expert to continue the study. The process continued as far as possible and 41 samples were asked orally or electronically.

To collect data of Dematel paired comparison questionnaire the same approach were used and 117 of experts answered the questionnaire.

In the third questionnaire, as both gap analysis and Structural equation modeling were used, proposed model of Barclay et al. (1995), Gefen et al. (2000) and Gefen et al. (2011) were used. In this method the least sample size needed for using PLS is the largest value contained from the two rules (Hair et al., 2013).

- 10 multiplied by number of indexes/questions of the questionnaire of measurement model that have the most indexes among measuring models of the main model (variable indexes that have the most indexes). In this study, the variable (process and implementation has 9 indexes $(10 \times 9=90)$.

- 10 multiplied by the most existing relationship in structural part of the main model that is related to one variable. In this study the most structural relationship ( 2 input and 2 output, totally 4 relationship) for the variable is "Physical environment" $(10 \times 4=40)$.

Thus, at least 90 samples are needed. To be more certain, 30\% more questionnaires were distributed (120) from which 110 questionnaires were accepted.

\section{Findings}

\subsection{Delphi Method}

In Delphi method, in 3 stages 41 ideas of respondents were studied and 17 indexes were obtained that were classified in 8 main groups (Table 1).

Table 1. Indexes of Delphi model

\begin{tabular}{|c|c|}
\hline Factor (Dimension) & Indexes \\
\hline Road direction & ving suitable road for ground transportation \\
\hline & work to offshore area/ capacity of rail $n$ \\
\hline Sea port & traffic/ capacity of ports and ships \\
\hline $\begin{array}{l}\text { Structure } \\
\text { infrastructure }\end{array}$ & ility of future development and productivity/ appropriate facilities and information \\
\hline $\begin{array}{l}\text { Process and } \\
\text { implementation }\end{array}$ & $\begin{array}{l}\text { Government support/ knowledge and human resource specialists/ on time delivery, } \\
\text { supportive services (such as repairing container in intermodal network) }\end{array}$ \\
\hline inancial & eration of priv \\
\hline Environmental & Environmental protection $\quad$ (decrease in pollution) \\
\hline Physical environment & $\begin{array}{l}\text { Container storage capacity (place of keeping)/ having proper physical space (vast area) } \\
\text { for developing dry port }\end{array}$ \\
\hline
\end{tabular}




\subsection{Validity and Reliability}

In final part of the study, all internal consistencies of construct are more than 0.7. Results of compound reliability test and Cronbach's alpha are represented in table below and showed that research tool is reliability.

Table 2. Compound reliability test

\begin{tabular}{|c|c|c|c|c|c|c|}
\hline & AVE & Composite & Reliability R Square & Cronbach' & s Alpha Communality & Redundancy \\
\hline Environmen & 0.8043 & 0.891576 & 0.527724 & 0.757434 & 0.804388 & 0.423676 \\
\hline Finance & 0.6518 & 0.918068 & & 0.893021 & 0.651832 & \\
\hline Physical & 0.6864 & 0.916044 & 0.863162 & 0.884869 & 0.686496 & 0.507626 \\
\hline Process & 0.6141 & 0.934371 & 0.873271 & 0.921026 & 0.614163 & 0.214725 \\
\hline Rail & 0.5525 & 0.855561 & & 0.786828 & 0.552594 & \\
\hline Road & $0.7351^{\prime}$ & 0.892745 & & 0.820181 & 0.735176 & \\
\hline Sea & 0.6242 & 0.908786 & & 0.879610 & 0.624258 & \\
\hline Structure & 0.6506 & 0.917733 & 0.750441 & 0.892302 & 0.650660 & 0.270418 \\
\hline
\end{tabular}

On the other hand, AEA that is higher than 0.5 in the above table shows that measurement tool is reliable. Results showed cross loadings, cross loading of each item on its construct and on other construct. Load factor of each item in its construct is 0.1 higher than its load factor on other construct, and also correlation between variables of tested model (Latent Variable Correlations) is lower than the square root of AVE of each construct, so divergent validity of the tool is verified.

Moreover, investigation of the quality of tested measurement tool based on positive values of the two indexes of CV-Red and CV-Com represent quality of measurement tool.

\subsection{Gap Analysis}

Regarding Kolmogorov-Smirnov test, statistics value of $\mathrm{z}$ was 0.733 and sig. value was that verified normal observation. Thus, for gap analysis paired comparison test was used. Significant value, that is lower than 0.05 , shows differences between current situation and expected situation. In other words, the table shows that there is a significant difference between perceptions and expectation of capability (factors) of implementation of dry port in Iran. This condition is true for average of all questions of the questionnaire (ninth comparison). Therefore, there is a challenge for all factors in the country and causal relationship of all factors is investigated.

Table 3. Paired Samples Test

\begin{tabular}{|c|c|c|c|c|}
\hline \multirow[t]{2}{*}{ Comparing Present -Expect } & \multicolumn{3}{|c|}{$\begin{array}{l}\text { Paired Differences } \\
\text { 95\% Confidence } \\
\text { t Situation Interval of the Difference }\end{array}$} & \multirow[t]{2}{*}{ df Sig. } \\
\hline & & Lower & Upper & \\
\hline Road direction & F1 - E1 & .013116 & .171408 & $2.310 \quad 109.023$ \\
\hline Rail network & F2 - E2 & -.164640 & -.020360 & -2.541109 .012 \\
\hline Sea port & F3 - E3 & .053668 & .199037 & 3.445109 .001 \\
\hline Structure and infrastructure & $\mathrm{F} 4-\mathrm{E} 4$ & .125637 & .355856 & $4.145 \quad 109.000$ \\
\hline Process and implementation & F5 - E5 & .067201 & .323383 & $3.022 \quad 109.003$ \\
\hline Financial & F6 - E6 & .077713 & .294690 & 3.402109 .001 \\
\hline Environmenta & F7 - E7 & -.166842 & -.003721 & -2.072109 .041 \\
\hline Physical environment & F8 - E8 & -.169896 & .007125 & -2.822109 .005 \\
\hline All & $F-E$ & -.234832 & -.022311 & -2.398109 .018 \\
\hline
\end{tabular}

\subsection{Causal Analysis by Dematel}

In Dematel method, collected ideas of 17 expertise (different from Delphi method) were converted to verbal variables based on Lie (1999) and related calculation was done.

Based on the calculations, $(\mathrm{D}-\mathrm{R})^{\mathrm{def}}$ and $(\mathrm{D}+\mathrm{R})^{\mathrm{def}}$ value to identify cause and effect were obtained as below. 
Table 4. Output of Dematel Method

\begin{tabular}{lllll}
\hline Cause or Effect & $(\mathbf{D}+\mathbf{R})^{\text {def }}$ & $\mathbf{( D - R}^{\mathbf{d e f}}$ & Cause or Effect & Rank \\
\hline Finacial & 10.19 & 1.99 & Cause & 1 \\
Rail network & 8.28 & 0.52 & Cause & 2 \\
Road direction & 7.44 & 0.10 & Cause & 3 \\
Sea ports & 6.33 & 0.37 & Cause & 4 \\
Structure and infrastructure & 6.05 & -0.75 & Effects & 5 \\
Process and implementation & 5.33 & -0.23 & Effects & 6 \\
Physical environment & 5.67 & -1.38 & Effects & 7 \\
Environmental protection & 4.84 & -0.62 & Effects & 8 \\
\hline
\end{tabular}

As the table shows, finacial, rail netwoek, road directions and sea ports factors that show positive D-R valueare the causes and implementaion process, environment, physical invironment, structure and infrastructure factors that shows negative D-R are the effects. In this part, based on obtianed information from researchliterature and directed interviews (based on that literature) of experties and specialists in this area, cause and effect relationship are proposed more preciselyin a primary molel. 4 identified variables as causes are dependent variables and 4 effects are defined as mediators. Based on the resutls of this part and litrarure review, aconceptual model is proposed below.

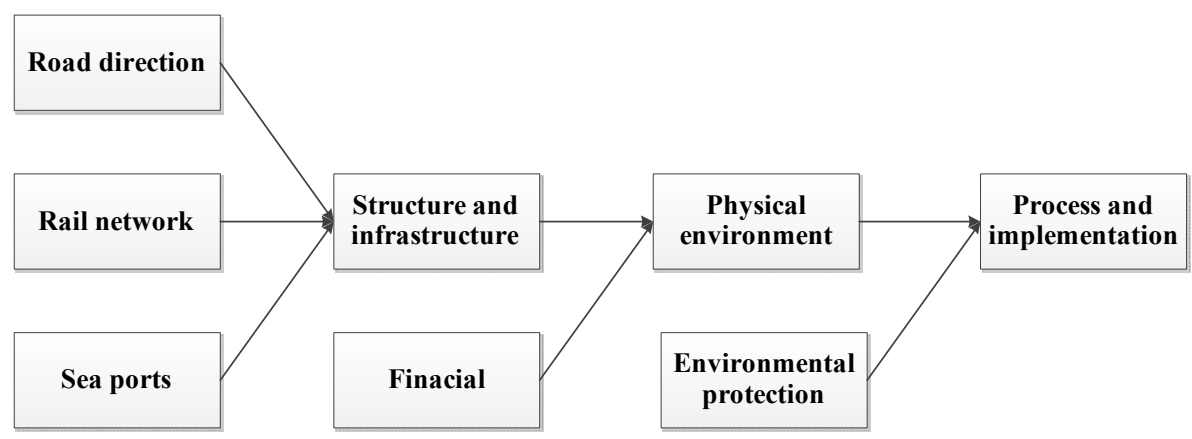

Figure 1. Research Conceptual Model

\subsection{Research Model Test}

\section{(A) Structural Model Test}

To evaluate defined relationships in the model (based on the data), $\mathrm{t}$ test was used. The result are illustrated in Figure 2.

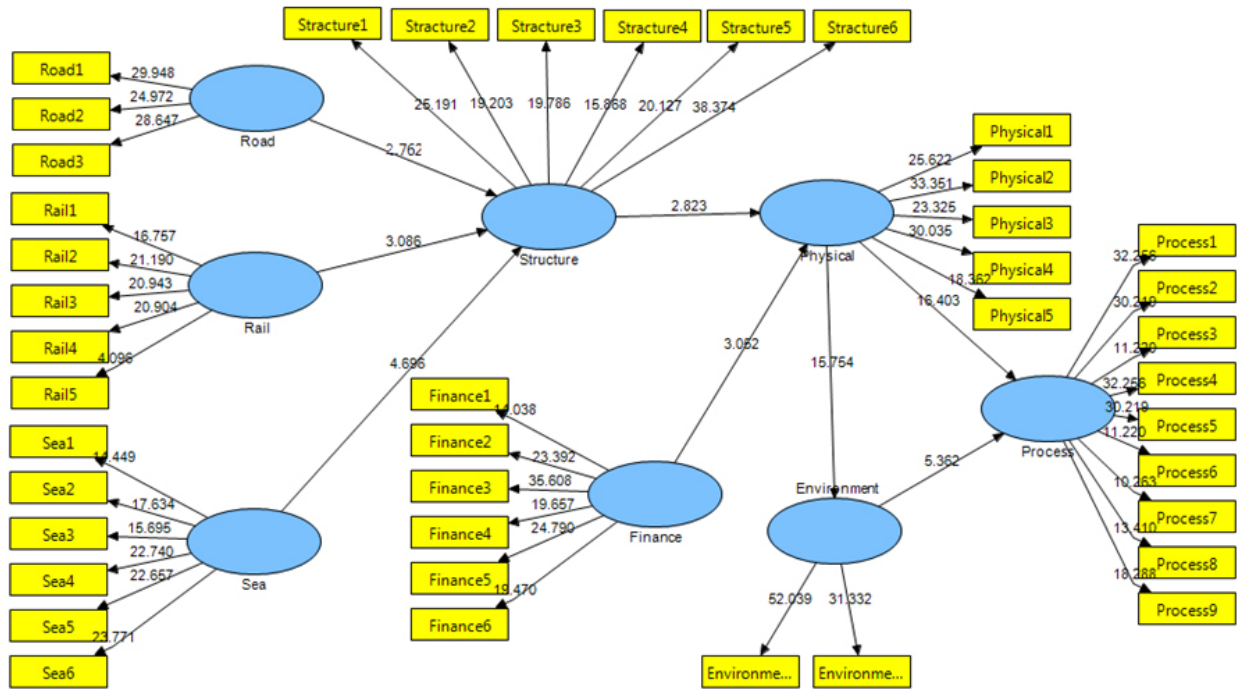

Figure 2. Results of the research model $t$ tests 


\section{(B) Direct and Indirect Effecttest}

In order to test structural model and to see its detailes, path coefficients values are illustrated in a tabele. As it is shown, independent variables are in the first column and dependent variables are in the first row, and for each causal relationship direct effect coeficient is stated.

In addition, path coefficients values of these relationship are presented in the table. The values represent possible indirect effects onthe relationships. For instance, financial variant has direct effect of 0.579715 on physical environment, and physical environment has direct effect of 0.726446 on the environment. So, indirect effect of financial variant on environmental variant is equal to multiplication of these to numbers 0.421132 .

Table 5. Path Coefficients

Direct effect of causal relationships

\begin{tabular}{lccc}
\hline & Environment Finance Physical & Process & Rail Road Sea Structure \\
\hline Environment & \multicolumn{2}{c}{0.768182} & \\
Finance & 0.579715 & \\
Physical & 0.726446 & 0.721315 & 0.713673 \\
Process & & & 0.746398 \\
Rail & & & 0.759554 \\
Road & & & \\
Sea & & & \\
Structure & & & \\
\hline
\end{tabular}

Indirect effect of causal relationships

\begin{tabular}{|c|c|c|c|c|}
\hline & Environment Finance & Physical & Process & Rail Road Sea Structure \\
\hline Environment & & & 0.768182 & \\
\hline Finance & 0.421132 & 0.579715 & 0.418157 & \\
\hline Physical & 0.726446 & & 0.721315 & \\
\hline Process & & & & \\
\hline Rail & 0.390088 & 0.536982 & 0.387333 & 0.713673 \\
\hline Road & 0.407976 & 0.561605 & 0.405094 & 0.746398 \\
\hline Sea & 0.415167 & 0.571504 & 0.412234 & 0.759554 \\
\hline Structure & 0.546593 & 0.752421 & 0.542733 & \\
\hline
\end{tabular}

\section{(C) Identified Changes Percentage Test}

To understand predicted percentage of changes by each variant, identified variance for each hidden variance was used. These values show that identified variance for process and implementation variant is 0.873271 . Moreover, physical environment variant with 0.863162 the highest power to predict dependent variables. Structure and infrastructure with 0.750441 and environment variant with 0.527724 the lowest capability of prediction.

\section{(D) Direction Significance Test}

As it is shown in Figure 2, related test showed that significance of all defined relationships in the model are higher than 1.96 whose confidence level is $95 \%$. Thus, all relationships are verified.

\section{(E) Fitness of the Model}

Fitness of the model is the criterion related to total part of Structural equation modeling that is measured by GOF. This criterion is equal to square root of multiplication of averages of R2s (0.75365) by average of Communalities (0.664946). The criterion is equal to 0.70791. Based on classification of value of R2 Kohen (1988) and by means of the least 0.5 Fornel and Larkel (1981) for unity level, GOF criterion value of 0.1 with regard to the sample is acceptable. Being higher than 0.7 implicates good fitness of the model.

\section{Conclusion}

Necessities and capabilities needed to implicate dry port in Iran and other countries are not generally different and most effective factors in this area is similar and common. Some of these effective factors are internal factors and some are external factors that have an impact of implementation of dry port. As Pettit (2008) stated: Evidently, different views about role of internal and external factors in development of intermodal terminals, 
affects related goals and strategies and competition level.

In the first part of the research (Delphi method) transportation capacity of rail network, capacity of places where containers are maintained, having suitable roads for ground transportation and government support are identified as the four most important factors. As Monios (2011) stated making high capacity transportation network is one the most basic objective of developing dry port. However, researches showed that heavy investment on capacity of terminal of containers and huge ships and circulation of containers impose incentive load on the operation of coastal ports (Moraoet all, 2000; McCalla, 2007).

Increase of port capacity through physical development (MacCalla, 1999) along with increased cost and considerable effort (Roso, 2008), adding conventional facilities, improving efficiency by new technology (Bian, 2011), organizing the works (Pekin, 2007), optimizing use of information systems (Kim and Moon, 2003). In between, governmental strategies to regulate and develop sea terminals are significantly important. That is why this role in some countries (like what was reported about Sweden dry ports) is direct. Therefore, one of the problems of implementation of dry port in Iran is that by governmental bill concerning developing dry port 2008, government is required to develop a dry port, but role of government is not precisely mentioned. Investigations showed that most project managers of dry ports suffer from uncertainty and limitation of government support. That is, in some cases scopes of duty is not defined, so government shirks responsibilities and delegate them to private sectors.

Moreover, knowledge and human resource specialists is in the fifth priority that suggests there is no science and technology in this area in the country. Investigating requirement of dry port development in Netherland, Olivier and Slack (2006) proposed knowledge exchange as a fundamental infrastructure. Roso (2011) introduced man power as a multipurpose tools in this area. Thus, to improve knowledge and technology, designing training courses or sending experts abroad to improve their knowledge is required.

Following priority is locating dry port. Vis and Koster (2003) believed that locating dry port is important for export and import volume, effect of environmental evolution, time and cost of delivery. In this regard, they support ideas of Zhang (2008), Zeng et al. (2014) and Liao, Tseng (2009) and they considered development status, traffic, work sources (work power of specialists and technology) and costs four fundamental factors.

Capacity of ports and ships is another important factor. As development of dry port lead to prosperity of business and international import and export, sea port should have capacity of high volume of ships and cargos. Cooperation of private sector is necessary when the country faces lack of financial resources or while it tries to help employment and economic prosperity, uses its energy in other areas.

Importance of the three indexes: port traffic, capacity of containers and investment risk in Iran suggests that there is a challenging situation in this area. So, these factor should be improved for a long term program. Having supportive services, facilities and information systems in addition to possibility of development and future efficiency are required as an additional tool. But, the concern is that this approach do not care about environment protection and reduction pollution (voice, air, water etc.). In this regard, Woxenius al. (2004) and Kreutzerberger et al. (2003) stated that although access to land in completion with sea is important, implementation of dry port always followed by energy consumption, traffic in road network. Low priority of in time delivery is interesting that represents trust of specialists in effectiveness of dry port projects. Region population, Geographical area and growth rate of supply and demand are less important indexes that are in final ranks with a large gap which is worrying. As mentioned before, congestion and traffic of the place of dry port implementation is a significant factor that has an effective impact on providing human resource and existing appropriate physical resources. Obviously, the congestion creates more needs for the region that dry port can respond to them. Finally, the lowest prioritized factor is growth rate of supply and demand. The reason might be imposed sanctions against Iran during the research that reduced the hope of import and export.

Table 6. Index prioritization based on obtained importance from Delphi method

\begin{tabular}{lcc}
\hline Index & $\begin{array}{l}\text { Respond average in } \\
\text { index verification stage }\end{array}$ & Rank \\
\hline Capacity of rail transportation network & 4.89 & 1 \\
Capacity of the place of maintaining containers & 4.89 & 2 \\
Existing suitable road to ground transportation & 4.82 & 3 \\
Government support & 4.81 & 4 \\
Knowledge and human resource specialists & 4.79 & 5 \\
\hline
\end{tabular}




\begin{tabular}{lll}
\hline Having appropriate physical space to develop dry port & 4.78 & 6 \\
Decrease in transportation costs & 4.767 & 7 \\
Extending rail network to offshore regions & 4.733 & 8 \\
Capacity of ports and ships & 4.67 & 9 \\
Private sector cooperation & 4.66 & 10 \\
Sea port traffic & 4.62 & 11 \\
Capacity of containers & 4.44 & 12 \\
Investment risk & 4.42 & 13 \\
Existing supportive services & 4.37 & 14 \\
Appropriate facilities and information system & 4.24 & 15 \\
Possibility of development and future efficiency & 4.21 & 16 \\
Environment protection & 4.111 & 17 \\
On time delivery & 4.100 & 18 \\
Region population & 2.809 & 19 \\
Form of dry port & 2.800 & 20 \\
Geographical area & 2.033 & 21 \\
Growth rate of supply and demand for sea import and export & 2.03 & 22 \\
\hline
\end{tabular}

Despite all mentioned priorities, gap analysis showed that lack of all factors is seen in the country (there is significant difference between current situation and desirable situation). This shortage can be considered as one the main reasons of failure in dry port projects. Because first, inefficiencies and deficiencies should be eliminated and then the capacities should be used for successful implementation of dry port.

Following investigations illustrated that these factors (classified in 8 groups in this part), affect each other's intensity and weakness, so identifying them is vital to implement dry port successfully. With this regard, identified relationships from Dematel analysis and suggested and tested model are significantly important. As Table 27.4 and 28.4 present, direct effects of relationships can have indirect impacts. For instance, while three variables of road direction, rail network and sea ports as three fundamental factor in dry port affect structure and infrastructure with load factor of 0.7 , it can indirectly influence on three variables of environment, process and implementation and physical environment. Interestingly, indirect impact of sea ports and road direction on physical environment is similar to direct impact that financial resources has on physical environment (this difference for rail network is not great). That is, while sea port development and its capacity help structural changes and development of infrastructures, it can affect physical environmental and it can be affective on its formation and use. Finally, it should be stated that although in other indirect relationships there is a significant differences between direct and indirect relationships, their synergy is inevitable and any deficiency and problem in this relationship can affect future stages of implementation of dry port projects. Therefore, it is required that in Iran independent variables (road direction, rail network, sea ports and finance) be considered and be amended and reinforced first. While the improvement in this area clarifies next stages, it can also facilitate successful implementation of dry port projects.

\section{References}

Baird, A. J. (2004). Public goods and the public financing of major European seaports, Maritime Policy \& Management, 31(4), 375-391.

Barclay, D., Thompson, R., \& Higgins, C. (1995). The Partial Least Squares (PLS) Approach to Causal Modeling: Personal Computer Adoption and Use an Illustration, Technology Studies, 2(2), 285-309.

Bergqvist, R., \& Wilmsmeier, G. (2009). Extending the Role and Concept of Dryports: A Response to the Public Consultation of a Sustainable Future for Transport: Towards an Integrated, Technology-led and User Friendly System. Dryport Project.

Bian, K. A. (2011). Application of Fuzzy AHP and ELECTRE to China dry port location selection, The Asian Journal of Shipping and Logistics, 27(2), 331-354.

Brooks, M. R., \& Cullinane, K. P. B. (Eds.) (2007). Devolution, Port Governance and Port Performance, Research in Transportation Economics, XVII. Amsterdam: Elsevier.

Christiansen, M., Fagerholt, K., \& Ronen, D. (2004). Ship routing and scheduling: Status and perspectives. Transportation Science, 38, 1-18.

Cordeau, J. F., Laporte, G., \& Mercier, A. (2001). A unified tabu search heuristic for vehicle routing problems 
with time windows. Journal of the Operational Research Society, 52, 928-936.

Cullinane, K. P. B. (2010). Revisiting the productivity and efficiency of ports and terminals: Methods and applications. In: C. Grammenos (ed.) Handbook of Maritime Economics and Business. London: Informa Publications, 907-946.

Cullinane, K. P. B., \& Khanna, M. (1999). Economies of scale in large container ships. Journal of Transport Economics and Policy, 33(2), 185-208.

Cullinane, K. P. B., \& Khanna, M. (2000). Economies of scale in large containerships: Optimal size and geographical implications. Journal of Transport Geography, 8(3),181-195.

Cullinane, K. P. B., \& Wilmsmeier, G. (2011). The contribution of the dry port concept to the extension of port life cycles. In: J.W. Bo"se (ed.) Handbook of Terminal Planning, Operations Research Computer Science Interfaces Series, 49. Heidelberg, Germany: Springer, 359-380.

Gefen, D., Rigdon, E. E., \& Straub, D. (2011). An Update and Extension to SEM Guidelines for Administrative and Social Science Research, MIS Quarterly, 35(2), Editor's Comments, A1-A7.

Gefen, D., Straub, D. W., \& Boudreau, M. C. (2000). Structural Equation Modeling and Regression: Guidelines for Research Practice, Communications of the Association for Information Systems, 4(7), 1-70.

Guan, Y., \& Cheung, R. K. (2004). The berth allocation problem: Models and solutions. OR Spectrum, 26(1), 75-92.

Hair, J. F., Hult, G. T. M., Ringle, C., \& Sarstedt, M. (2013). A Primer on Partial Least Squares Structural Equation Modeling (PLS-SE). Sage Publications, Inc.

Hansen, P., Oguz, C., \& Mladenevic, N. (2008). Variable neighborhood search for minimum cost berth allocation. European Journal of Operational Research, 191(3), 636-649.

Imai, A., Nishimura, E., Papadimitriou, S., \& Liu, M. (2006). The economic viability of container mega-ships. Transportation Research E, 42(1), 21-41.

Kim, K. H., \& Moon, K. C. (2003). Berth scheduling by simulated annealing. Transportation Research B, 37, $541-569$.

Kreutzerberger, E., Macharis, K., Vereecken, L., \& Woxenius, J. (2003). Is intermodal freight transport more environmentally friendly than all-road freight transport? A review, paper presented at NECTAR Conference, Umea, 13-15 June.

Liao, C. H., Tseng, P. H., Cullinane, K., \& Lu, C. S. (2010). The impact of an emerging port on the carbon dioxide emissions of inland container transport: an empirical study of Taipei port, Energy Policy, 38(9), 5251-5257.

Liao, C. H., Tseng, P. H., \& Lu, C. S. (2009). Comparing carbon dioxide emissions of trucking and intermodal container transport in Taiwan, Transportation Research Part D, 14(7), 493-496.

Londono-Kent, P. (2009). Freight Transport for Development Toolkit: Road Freight, WorldBank, Washington $D C$.

McCalla, R. J. (2007). Factors influencing the landward movement of containers: the cases of Halifax and Vancouver. In: Wang, J., Olivier, D., Notteboom, T., Slack, B. (Eds.), Ports Cities, and Global Supply Chain, first ed. Ashgate, 121-137.

Monios, J. (2010). The effect of maritime policy and funding on short haul shipping in Scotland. Paper Presented at WCTR, Lisbon, Portugal, July 2010.

Monios, J. (2011). The role of inland terminal development in the hinterland access strategies of Spanish ports. Research in Transportation Economics, 33, 59-66.

Mourao, M. C., Pato, M. V., \& Paixao, A. C. (2002). Ship assignment with hub and spoke constraints. Maritime Policy and Management, 29, 135-150.

Notteboom, T. (2004). Container shipping and ports: an overview, Review of Network Economics, 3(2), 86-106.

Notteboom, T. E., \& Rodrigue, J. P (2009). Inland terminals within North American \& European Supply Chains. In: Transport and Communications Bulletin for Asia and the Pacific No. 78: Development of Dry Ports. New York, UNESCAP.

Notteboom, T. E., \& Winklemans, W. (2001). Structural changes in logistics: how will port authorities face the 
challenge? Maritime Policy \& Management, 28(1), 71-89.

OECD. (2010). Globalization, Transport and the Environment, Paris.

Olivier, D., \& Slack, B. (2006). Rethinking the port. Environment \& Planning A, 38(8), 1409-1427.

Park, Y.M. and Kim, K.H. (2003). A scheduling method for berth and quay cranes. OR Spectrum, 25, 1-23.

Pekin, E., \& Macharis, C. (2007). A GIS-based location analysis model for intermodal terminals. Paper presented at International Logistics and Supply Chain Congress 2007; 8-9 November 2007, Istanbul, Turkey.

Pettit, S. J. (2008). United Kingdom ports policy: Changing government attitudes. Marine Policy, 32(4), 719727.

Robinson, R. (2002). Ports as elements in value-driven chain systems: the new paradigm. Maritime Policy \& Management, 29(3), 241-255.

Roso, V., \& Lumsden, K. (2010). A review of dry ports. Maritime Economics and Logistics 12(2): 196-213.

Roso, V., Woxenius, J. and Lumsden, K. (2009). The dry port concept: Connecting container seaports with the hinterland. Journal of Transport Geography, 17(5), 338-345.

Roso, V. (2008). Factors influencing implementation of a dry port, International Journal of Physical Distribution \& Logistics Management, 38(10), 782-798.

UNCTAD (1982). Multimodal transport and containerisation. TD/B/C.4/238/Supplement 1, Part Five: Ports and Container Depots. Geneva: United Nations Conference on Trade and Development.

UNCTAD (1991). Handbook on the Management and Operation of Dry Ports. Geneva: United Nations Conference on Trade and Development.

Van Klink, H. A., \& Van den Berg, G. C. (1998). Gateways \& intermodalism. Journal of Transport Geography, $6(1), 1-9$.

Vandervoort, C., \& Morgan, M. (1999). Reducing Transport Costs of Egypt's Exports, DEPRA Project, Nathan Associates Inc, Arlington, VA, USA.

Vis, I. F. A., \& Koster, R. D. (2003). Transshipment of containers at a container terminal: An overview. European Journal of Operational Research, 147, 1-16.

Woxenius, J., Roso, V., \& Lumsden, K. (2004). The dry port concept - connecting seaports with their hinterland by rail, ICLSP Conference Proceedings, Dalian, 305-319.

Zanni, A. M., \& Bristow, A. L. (2009). Emissions of CO2 from road freight transport in London: trends and policies for long run reductions, Energy Policy, 38(4), 1774-1786.

Zeng, Q. C. Maloni, M. J., Paul, J. A., \& Yang, Z. Z. (2014). Dry Port Development in China: Motivations, Challenges, and Opportunities, Transportation Journal, 52(2), 234-263.

Zhang, R. P., et al. (2008). Comprehensive Performance Evaluation of Logistics Center Layout Plan Based on Entropy Weight and ANP, Logistics Technology, 2, p25.

\section{Notes}

Note 1. Statistics sited by Dadvar, Arashahi and Tanzifi (2010).

\section{Copyrights}

Copyright for this article is retained by the author(s), with first publication rights granted to the journal.

This is an open-access article distributed under the terms and conditions of the Creative Commons Attribution license (http://creativecommons.org/licenses/by/3.0/). 